\title{
Elliptical shaft excavation and furnishing in response to depth induced ground pressure
}

\author{
GA Sturgis Hecla Limited, USA \\ DR Berberick Hecla Limited, USA \\ MP Board Hecla Limited, USA \\ WH Strickland Hecla Limited, USA \\ MT Swanson Cementation USA Inc., USA
}

\begin{abstract}
Hecla Limited is nearing completion of the Lucky Friday mine No.4 shaft located in Mullan, Idaho. The shaft is collared at the 4940 Level of the mine and will have a final mine level depth of 8620, or 2,923 $\mathrm{m}(9,590 \mathrm{ft})$ below the surface. After reaching the 7400 Mine Level the shaft encountered ground deformation higher then allowed for in the design for a circular shaft excavation and concrete lining. This additional ground deformation required portions of the shaft concrete liner to be reinforced with frameless, steel liner plate. To eliminate the installation of the liner plate from the remaining shaft development, the design of the shaft excavation starting at the 7650 Mine Level was changed to an elliptical cross-section based on the overall stress field orientation as well as the orientation of the structure of the host rock surrounding the shaft. The elliptical cross-section was instrumented to confirm the shaft excavation and lining was performing as designed. This design change has allowed the shaft to continue to the planned 8620 Mine Level without the need to install liner plate in the shaft or change the overall functionality of the shaft or the Lucky Friday life-of-mine plan.
\end{abstract}

Keywords: shaft sinking, ground pressure, ground support

\section{Introduction}

Hecla's Lucky Friday mine is a deep, underground producer of silver, lead and zinc in the Coeur d'Alene mining

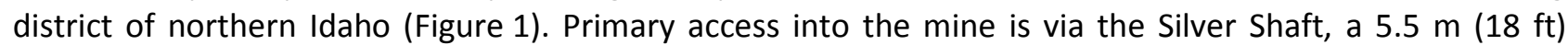
diameter, concrete lined shaft sunk to an original depth of $1,890 \mathrm{~m}(6,200 \mathrm{ft})$. Current production is from the Gold Hunter vein system, approximately 1,525 m (5,000 ft) northwest of the Silver Shaft.

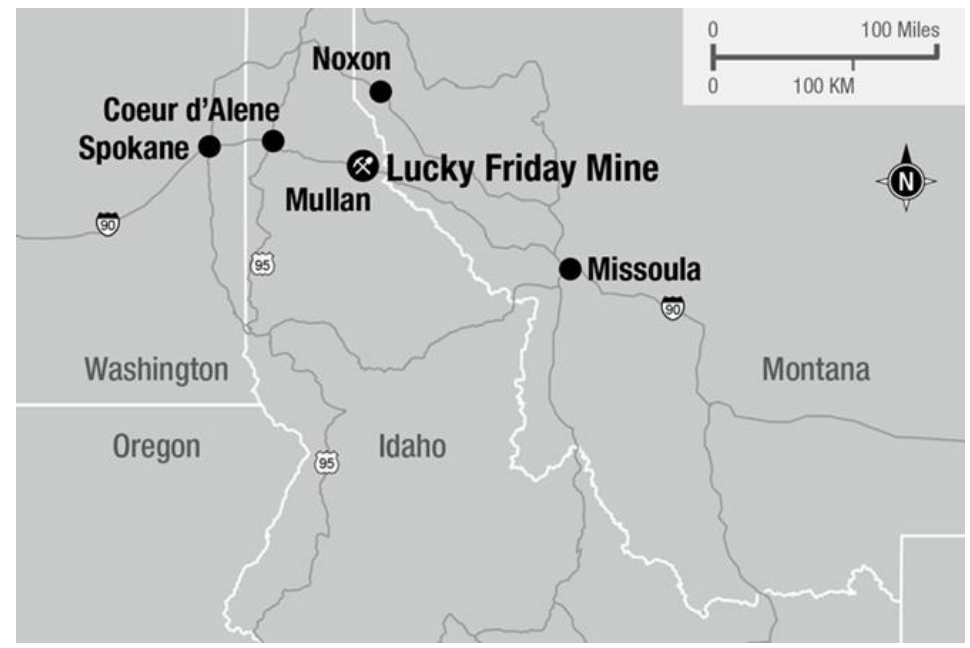

Figure 1 Location of the Lucky Friday mine 


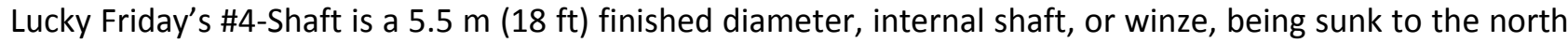
of the Gold Hunter vein system, from the mine's 4760 Level, 1,743 m $(5,720 \mathrm{ft})$ below the surface, to the 8620 Level, 2,923 $\mathrm{m}(9,590 \mathrm{ft})$ below the surface. The shaft is designed to provide access to the deep, high-grade zones of the Gold Hunter in order to increase the mine's production and operational life. Design and engineering began in 2006, with construction starting in the fourth quarter of 2009.

Three production levels with shaft stations are planned at the mine's 6500, 7500, and 8300 Levels. Twenty-four metres $(80 \mathrm{ft}$ ) below each production level is a skip loading pocket. Production muck will be

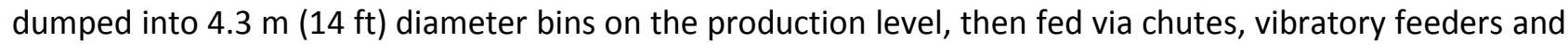
conveyor to skip loading flasks at the shaft (Strickland et al. 2016).

This paper discusses the implications of depth induced ground pressure on sinking and furnishing of Lucky Friday's \#4-Shaft. Back ground information is provided on the geology and ground support used on the project. The final solution on to accommodate the depth induced ground pressure is described. Future analysis as part of larger lessons learned exercise is summarised.

\section{Geology}

The Gold Hunter orebody is hosted in the pre-Cambrian Wallace formation of the Belt Supergroup. The Wallace formation consists of thinly bedded argillites with a roughly east-west strike and a near vertical dip (Figure 2). These bedding/foliation planes are typically coated with talcy minerals. The rock mass has an estimated rock mass uniaxial compressive strength of $48 \mathrm{MPa}(7,000 \mathrm{psi})$, (Pakalnis 2008), which is highly anisotropic, being distinctly weaker perpendicular to the foliation. The maximum in situ stress strikes roughly northwest-southeast with a ratio of maximum horizontal to vertical stress of about 1.5 to 1 .

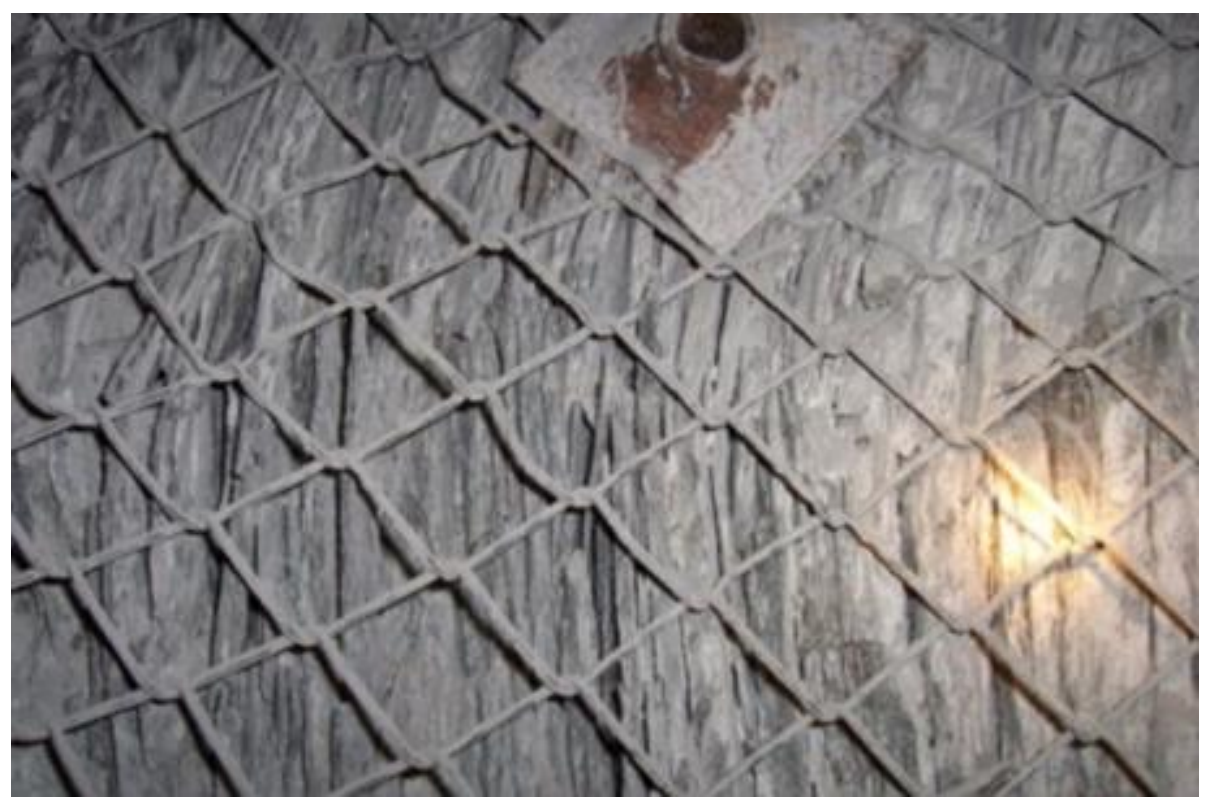

Figure 2 Typical vertical bedding (foliation) of less than $15 \mathrm{~mm}$ in the argillites of the Wallace formation

Prior to excavation of \#4-Shaft, it was recognised that the primary failure mode of the ground would be buckling and opening of the beds when excavating parallel to bedding. Bored raises had shown buckling of the north and south walls in the past (Figure 3). 


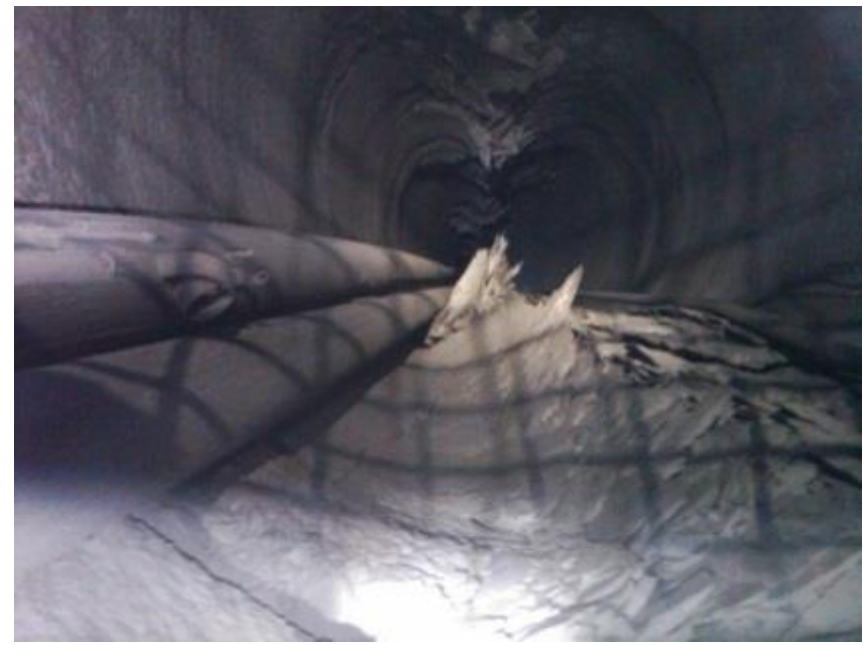

Figure 3 Buckling of argillite beds in north and south walls of a $1.8 \mathrm{~m} \mathrm{(6ft)} \mathrm{diameter} \mathrm{bored} \mathrm{raise}$

\section{Initial ground support design and excavation}

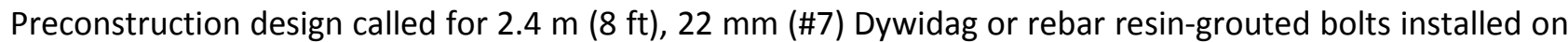

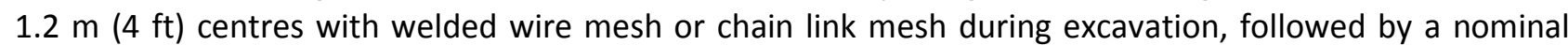

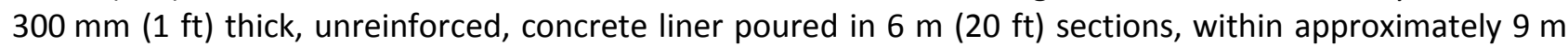
$(30 \mathrm{ft})$ of the advancing face.

The self-consolidating concrete (SCC) mix used in the shaft is supplied by a surface batch plant and delivered through a $150 \mathrm{~mm}$ (6 in) inside diameter borehole slickline to the mine's 4900 Level where it is loaded into transmixers and transported to \#4-Shaft collar. Concrete is then loaded into buckets and lowered to the shaft forms. Sampling follows American Concrete Institute (ACI) standards, with one sample set taken for every 38 cubic meters $\left(50 \mathrm{yd}^{3}\right)$ at the pour site by $\mathrm{ACl}$ certified technicians. Samples are cured and tested in a certified, onsite laboratory. The 28-day compressive strength of the SCC mix has been averaging over $50 \mathrm{MPa}$ (7,400 psi).

There had been discussions during design of the potential need to change the excavation shape to control the

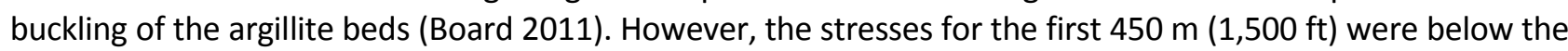
intact unconfined compressive strength of the rock, possibly due to being in the stress shadow of the mined out stopes south of the shaft, and the ground proved to be stable. Consequently, ground support was reduced

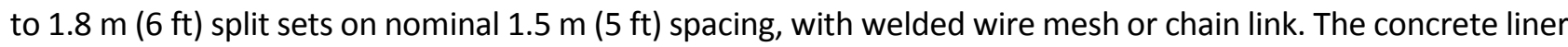
was kept within approximately $12 \mathrm{~m}$ (40 ft) of the bench. Virtually no ground water was encountered during sinking. As evidence of the lack of time-dependent deformations, the shaft remained stable for 16 months of

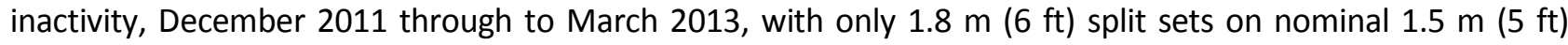
spacing, with welded wire mesh or chain link while the mine's Silver Shaft was rehabilitated.

\section{Shaft liner issues appear}

The 6500 shaft station, 2,274 m (7,460 ft) below the ground surface, was cut in early January 2014, without incident, although bowing of the hanging rods between the brow and the sill was noted as the shaft was sunk below the level. The first report of cracking in the liner was made on 31 January 2014, with report of a large

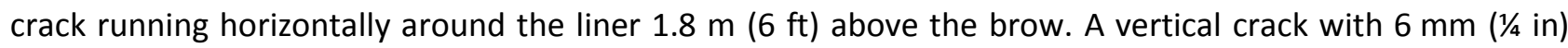
offset appeared in the north wall at the same elevation in early February, with spalling and breakout to a hanging rod reported soon after.

Believing this fracturing to be caused by opening and buckling of the argillite beds as had been seen in the bored raises, shaft ground support was increased to include cable bolting prior to placing concrete. Resin

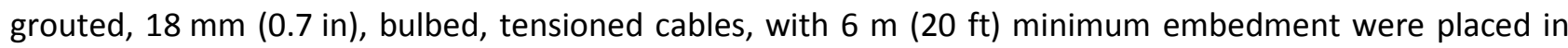

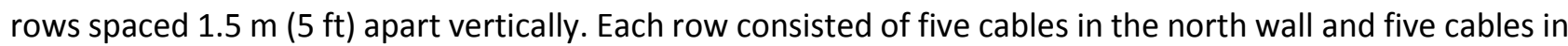

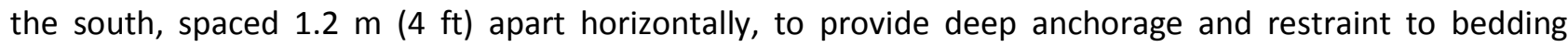




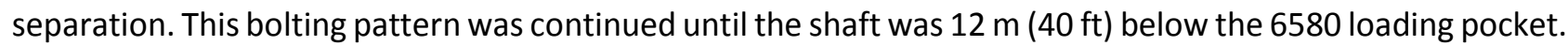
No difficulties with ground control were noted between the cessation of cable bolting below the 6580 and the approach to the 7500 Level.

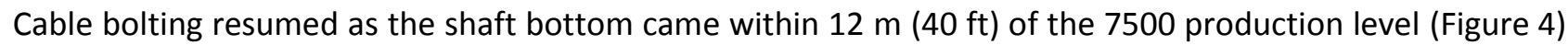
approximately $2,580 \mathrm{~m}(8,460 \mathrm{ft})$ below the ground surface, on 22 July 2014 . The concrete liner was completed to the brow of the 7500 shaft station in early August of that year, and excavation of the level began. By 28 October, the shaft had reached the brow of the 7580 Level, and severe, vertical fracturing of the north wall of the concrete liner above the 7500 brow developed. Shaft ground support was increased to

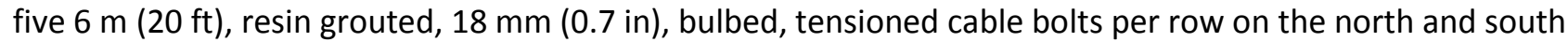
walls spaced on a $1.2 \times 1.2 \mathrm{~m}(4 \times 4 \mathrm{ft})$ pattern, with $3.6 \mathrm{~m}(12 \mathrm{ft})$ Dywidags placed midway, or 'five spotted', between them (Figure 5).

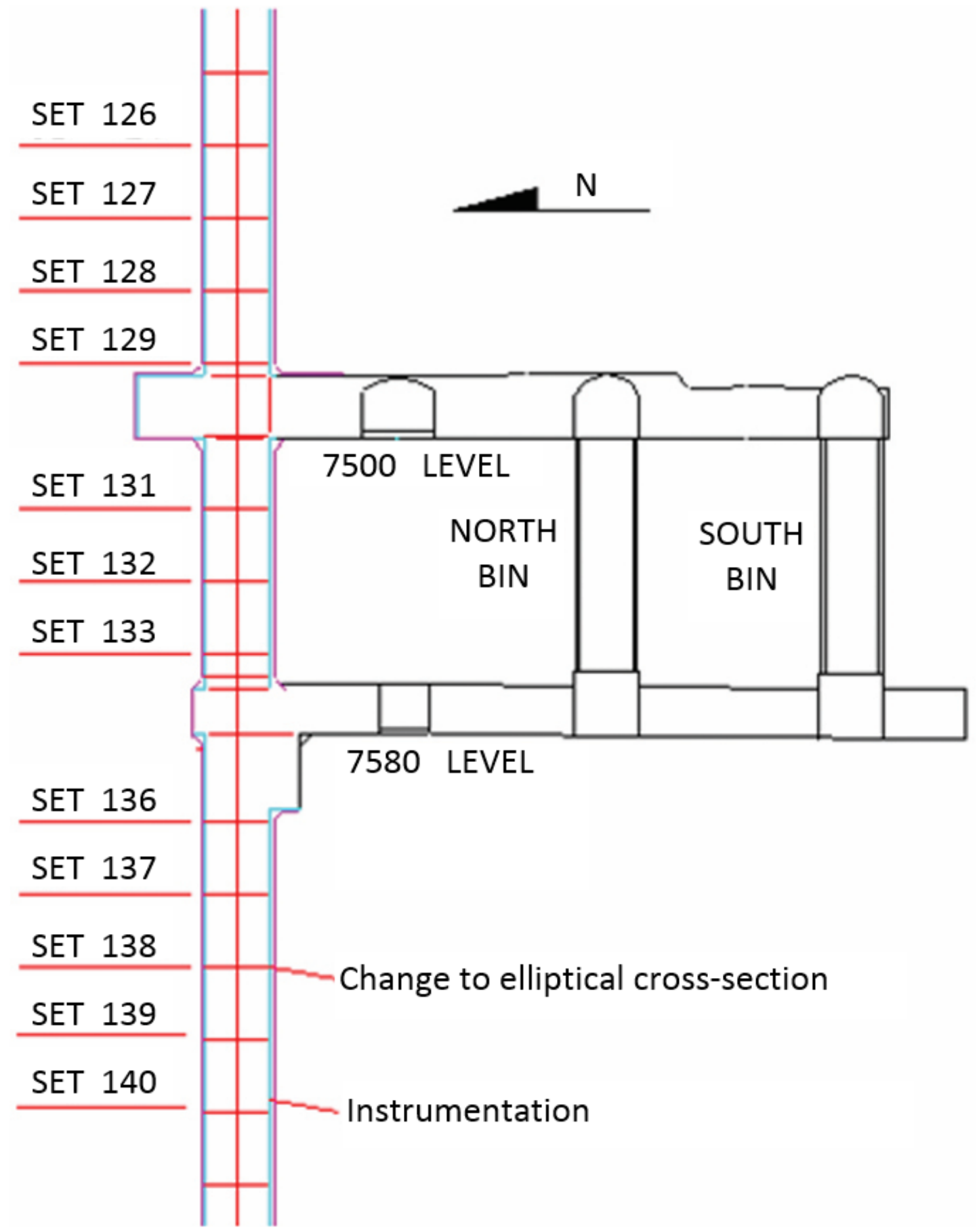

Figure 4 Vertical section of the shaft at the 7500 and 7580 Mine Levels 


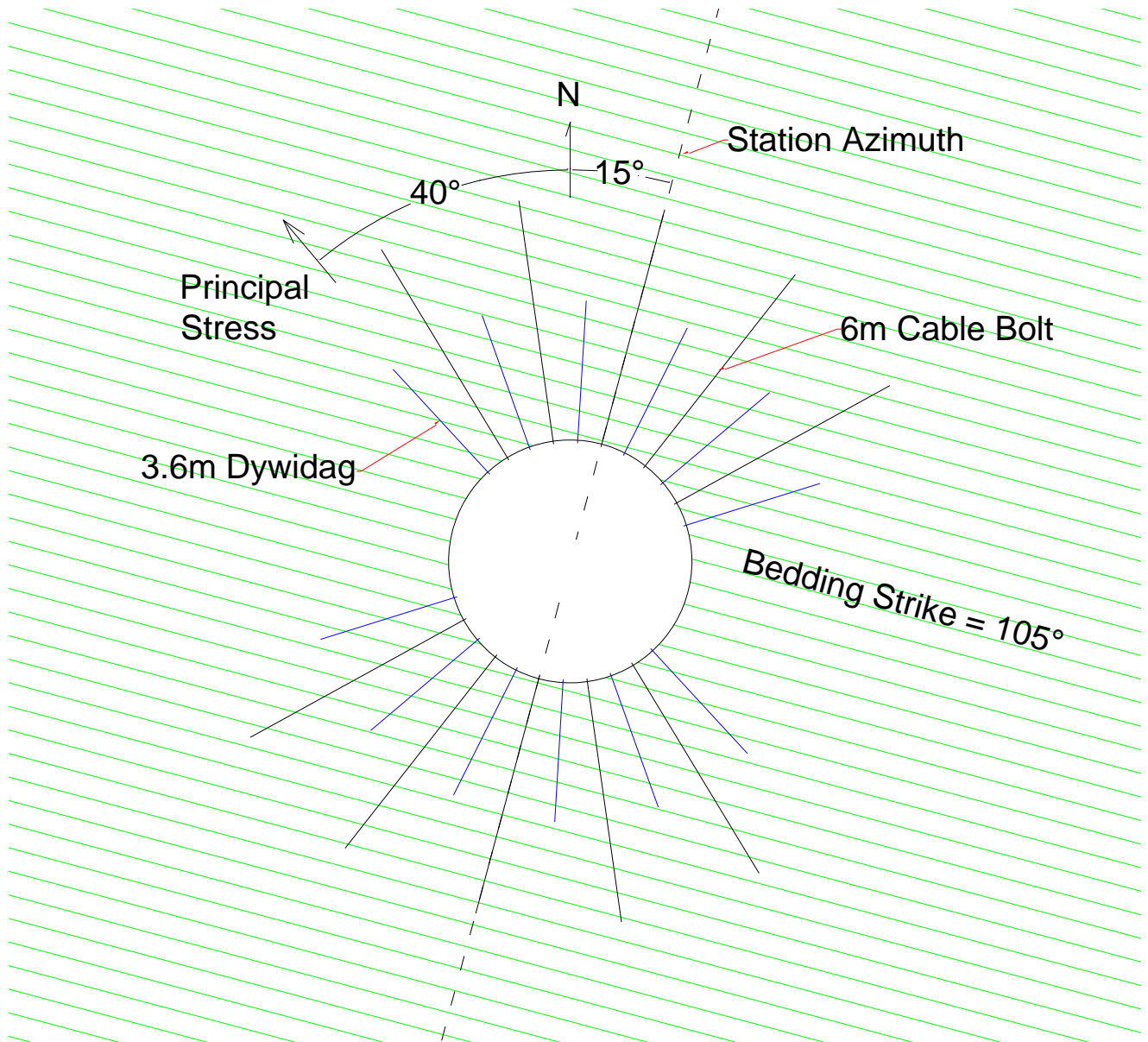

Figure 5 Ground support installation beginning at the 7580 Level

Cracking of the shaft liner between the 7500 and 7580 Levels began in early November with some simple flaking and spalling at set 132, approximately midway between the two levels. At that time, the decision was made to install shaft instrumentation to monitor rock mass radial deformations as well as tangential and radial stresses induced in the concrete liner. A study also began on alternative shaft excavation shapes to improve stability as considered in the preconstruction design. Damage to the existing concrete liner continued and expanded, ultimately stretching from $30 \mathrm{~m} \mathrm{(100} \mathrm{ft)} \mathrm{above} \mathrm{the} 7500$ Level to $12 \mathrm{~m}$ (40 ft) below the 7580 Level, an extent of nearly $75 \mathrm{~m}(24 \mathrm{ft})$. This area eventually required installation of steel liner plate for reinforcement and, in some areas, actual demolition and replacement of concrete.

\section{Change in shaft excavation shape}

Traditionally, timbered shafts in the district were mined with "the long horizontal axis oriented normal to the bedding of the country rock. Experience has shown that such a position is best able to resist rock pressure at depth" (McWilliams 1960). After consideration, it was decided to change the excavation to a more elliptical shape with the long axis perpendicular to bedding, similar to the orientation of a timbered shaft, believing this would provide a more stable opening and reduce point loads on the concrete shaft lining. To examine the impact of such a non-circular shape, some simple numerical simulations of both circular and notched shaft cross-sections were run in UDEC Version 5, a 'discontinuum' type program developed by Itasca Consulting Group. The models simulated a series of thinly-spaced beds oriented east-west, with the major principal stress oriented N40W and assumed to be 1.5 times the vertical (gravity) stress, or about $100 \mathrm{MPa}$ (14,500 psi) (Figures 6 and 7). 


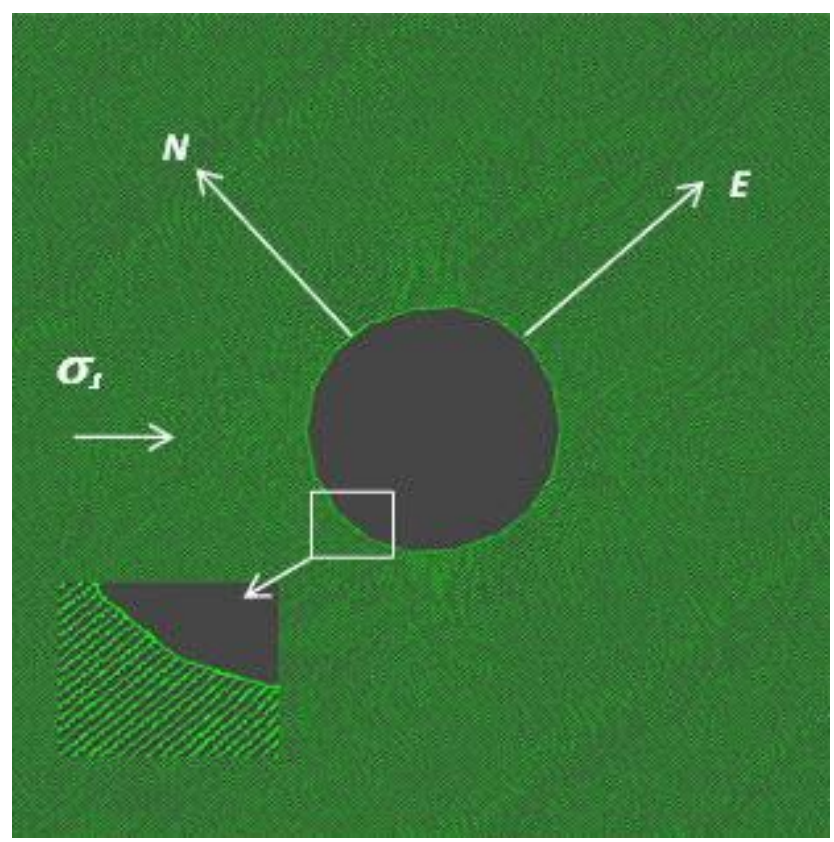

Figure 6 Circular shaft shape used in the model. The inset shows the model has a series of thinly spaced beds with an east-west strike

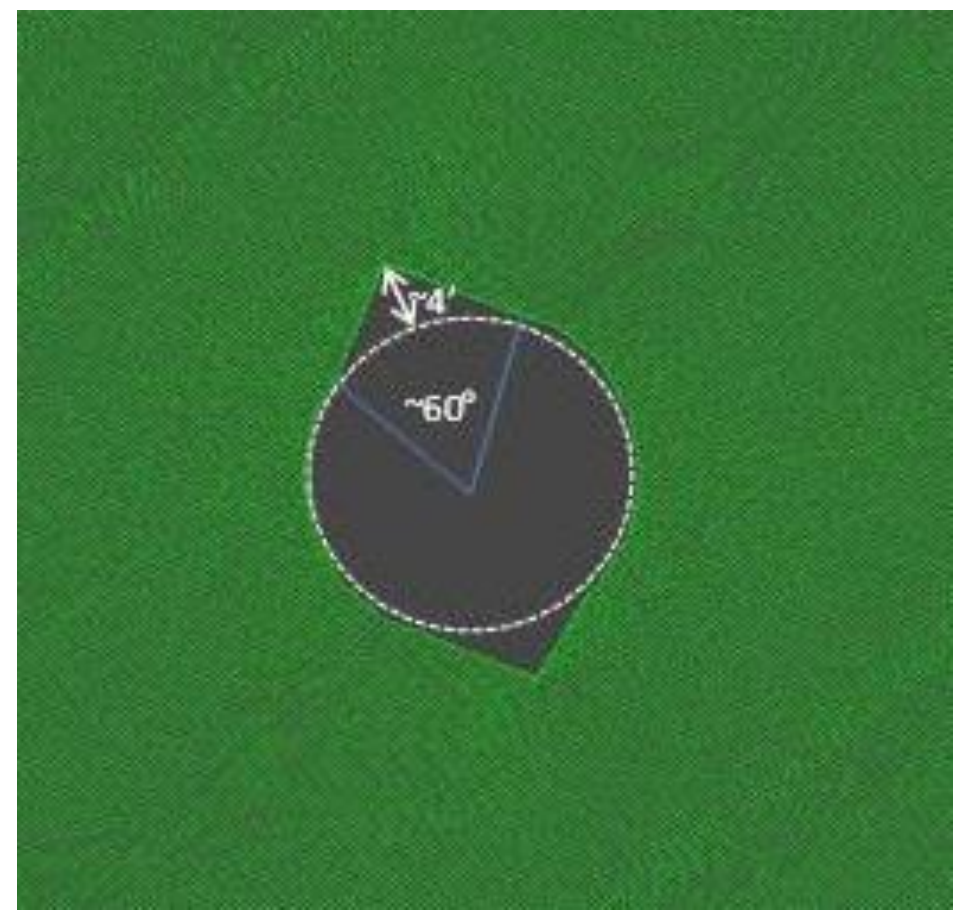

Figure 7 Notched $(1.2 \mathrm{~m})$ shaft cross-section used in the model

The simulation, as expected, showed the bedding tends to slip and buckle at the north and south sides of the shaft where the beds are more-or-less tangent to the wall in the circular case (Figure 8 ) as observed in other areas of the mine. As the thin beds, defined by foliation, buckle, they fracture in tension with resultant dilation into the opening. This mechanism was simulated with UDEC Version 5 by simulating discrete, narrowly-spaced joints characterised by zero cohesion and tensile strength and $20^{\circ}$ friction angle. The intact rock comprising the beds was given a Mohr-Coulomb material model with zero tensile strength cut-off. The

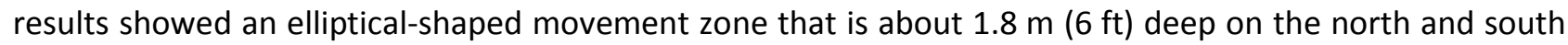
sides of the shaft (Figure 9). The maximum movement was shown to be directly perpendicular to bedding at opposite sides of the shaft. 


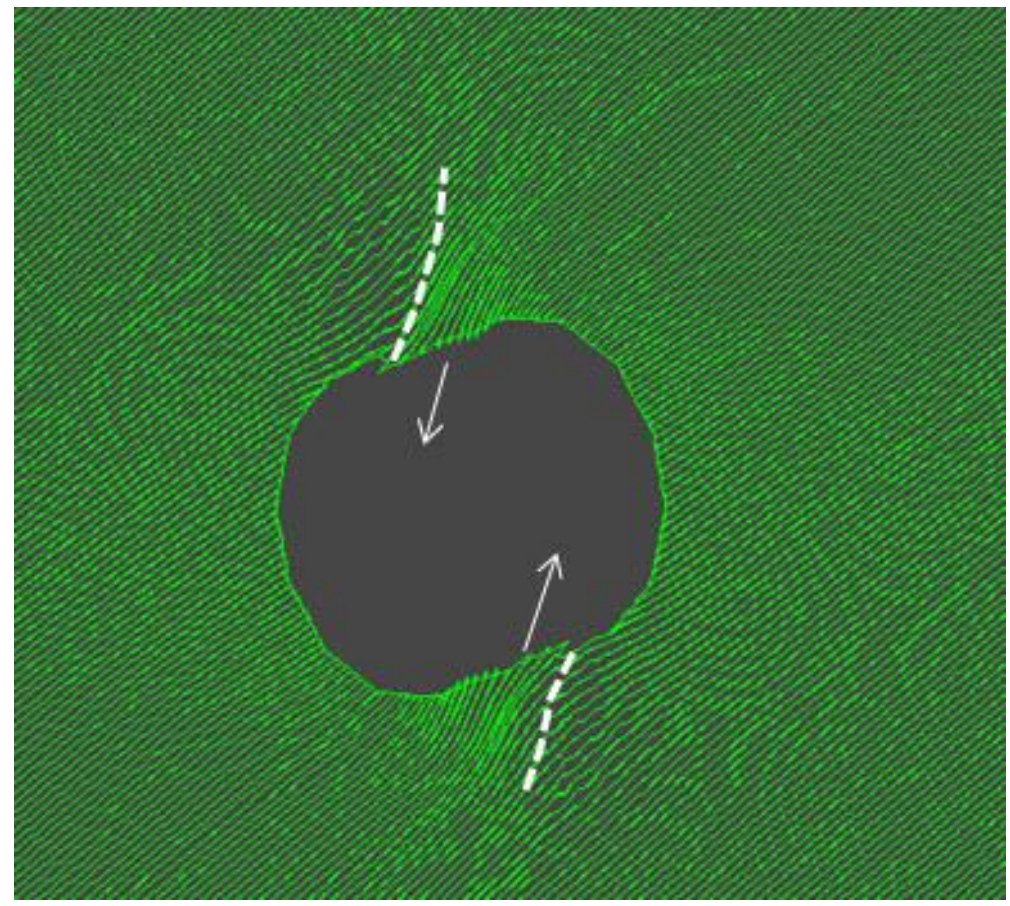

Figure 8 Magnified view of deformation showing mechanism of failure of the shaft walls with the circular shaft cross-section. The white dashed line shows where a kink forms at the north and south sides of the shaft, causing a wedge to push into the shaft

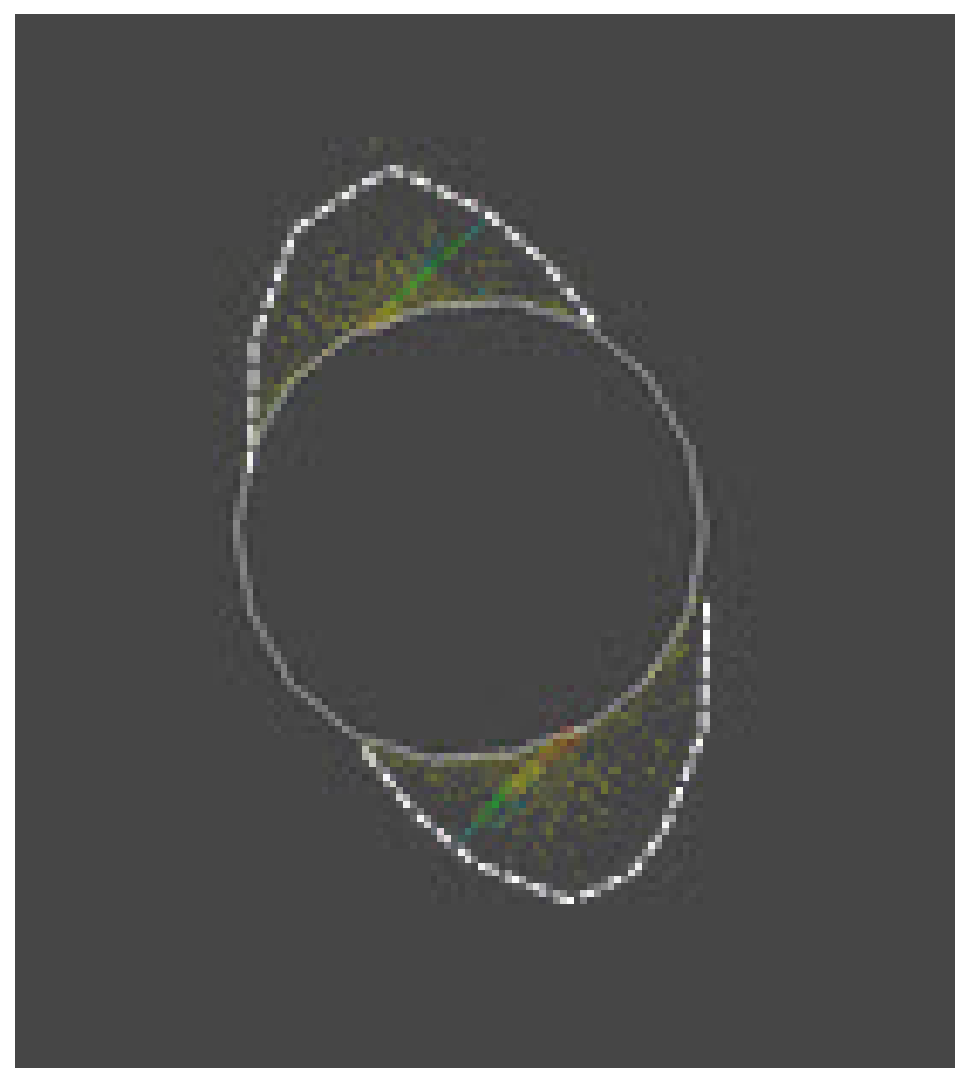

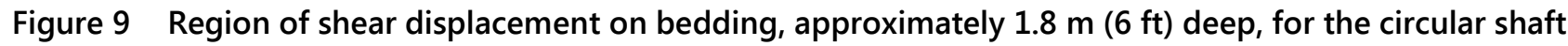
cross-section. Dashed, white line shows the elliptic-shaped failure zone

Figures 10 and 11 show the notch shape largely eliminates the buckling and shaft deformation. The only significant movement remaining was shear on bedding directly at the notch tip. 


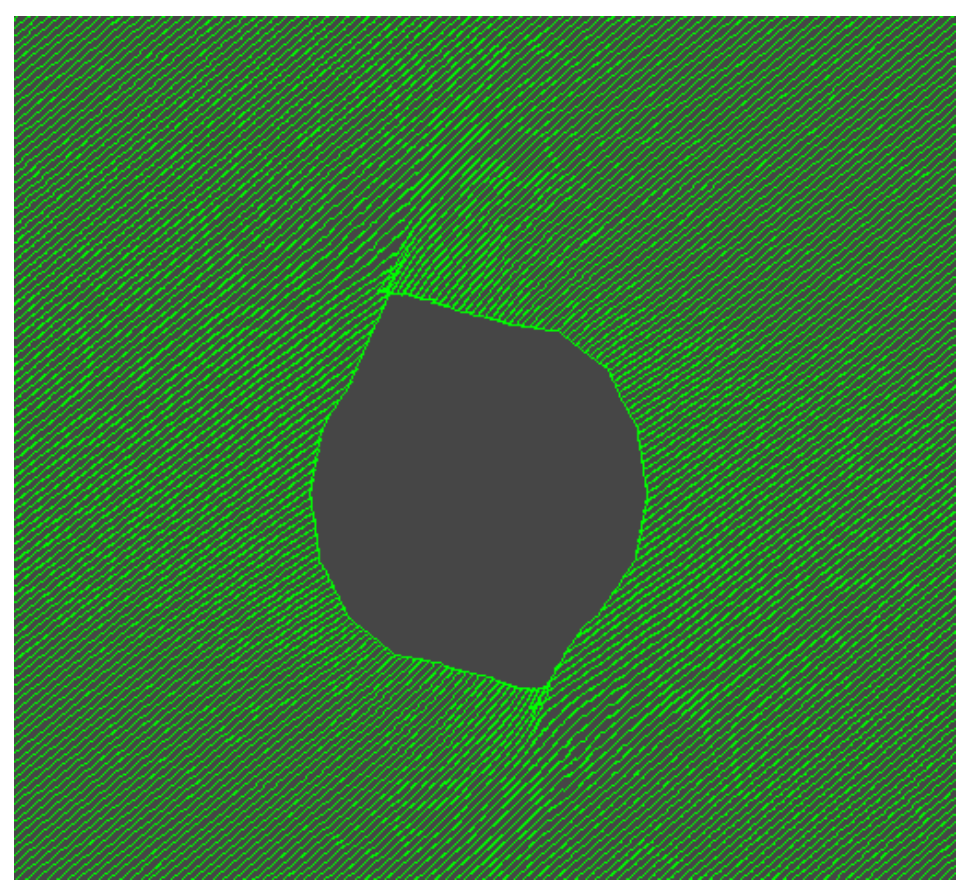

Figure 10 The notched cross-section prevents the formation of the wedge. Even though there is some shear at the tips of the notch, the cross-section maintains its original shape

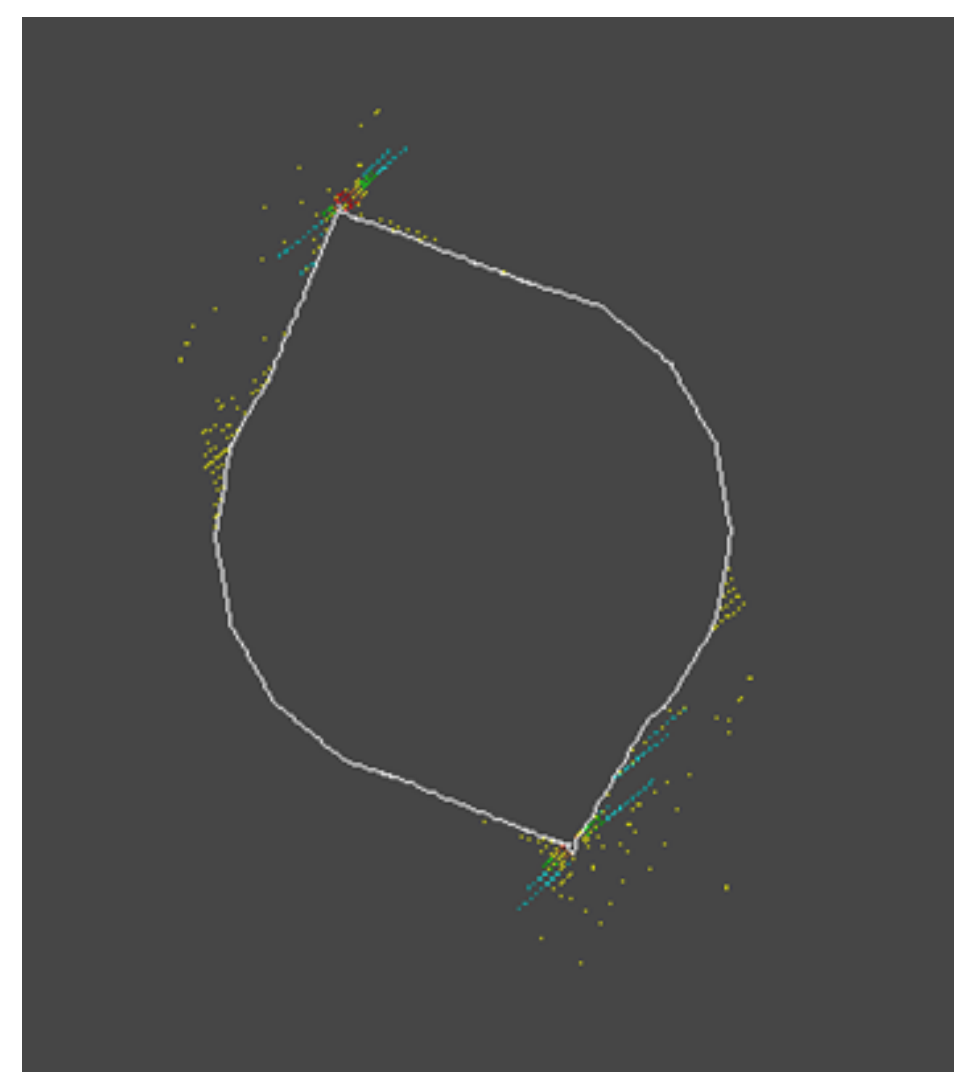

Figure 11 Failure region as shown by shearing bedding planes is largely eliminated by simply mining out the potential failed region before it is formed

Based on this modelling, the decision was made to change the excavated cross-section of the shaft to an elliptical shape, long axis perpendicular to bedding, with the final dimensions determined by the capabilities of the equipment being used to mine the shaft (Figures 12 and 13). 


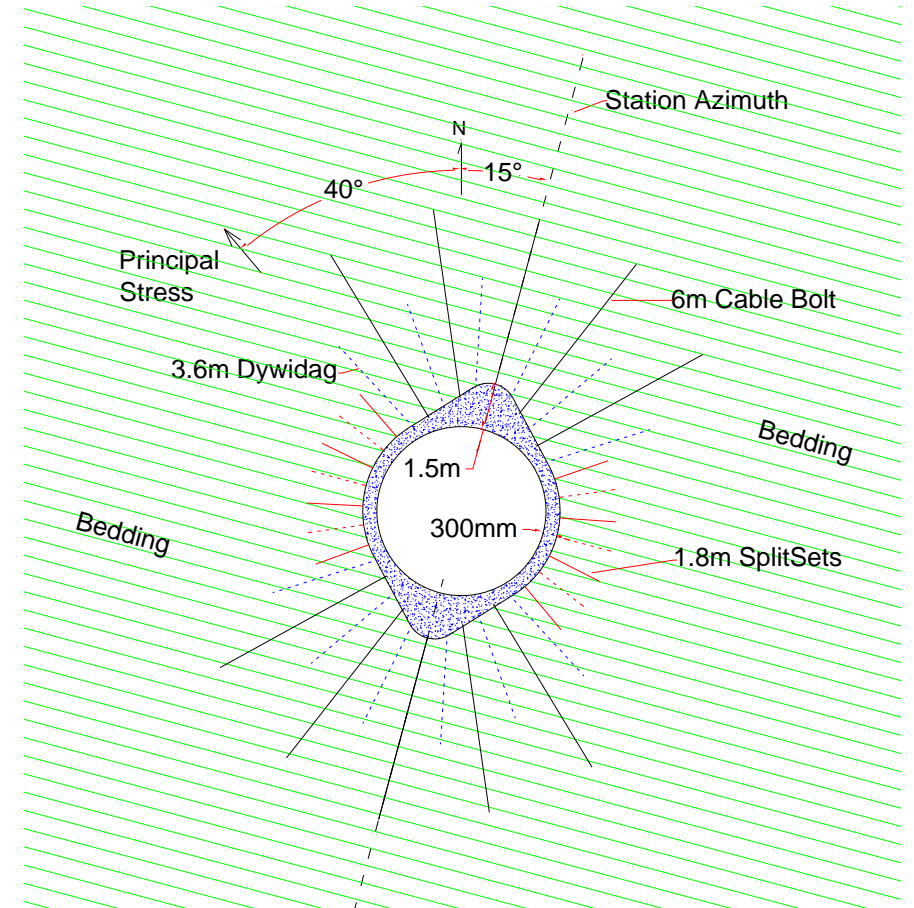

Figure 12 Shaft cross-section as redesigned. Cable bolts are only installed within $25 \mathrm{~m}$ (80 feet) above or below of shaft stations

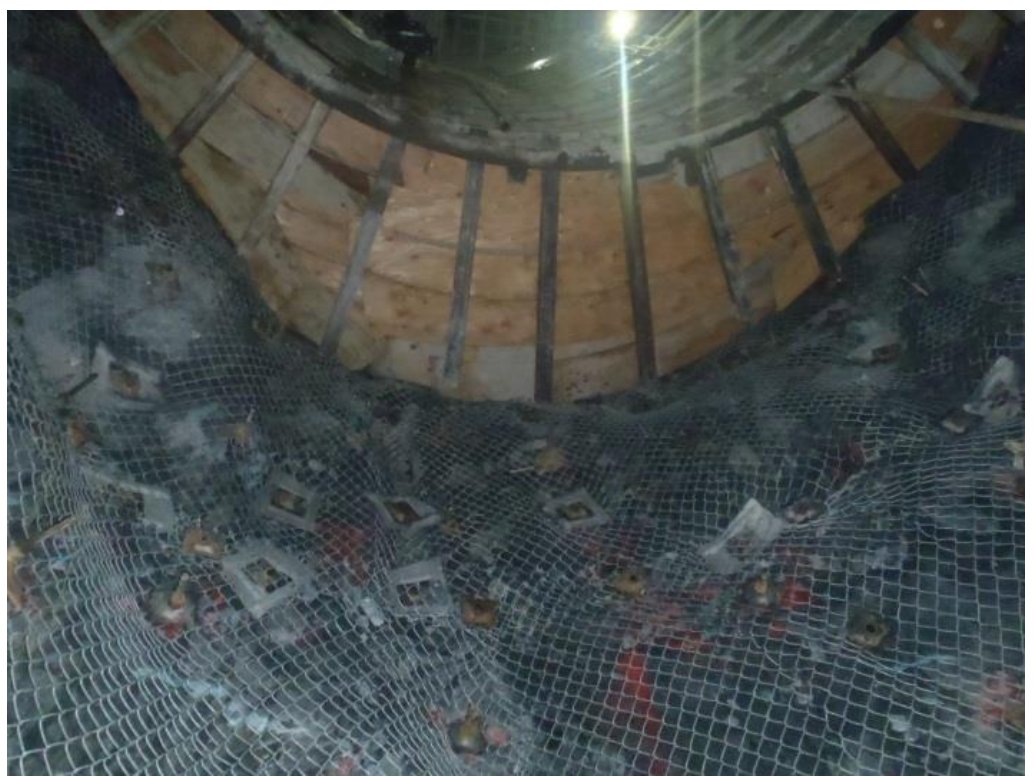

Figure 13 Looking up from the shaft bottom at the scribing on the bottom of the concrete forms. The elliptical excavation to the north of the shaft is clearly visible

\section{Instrumentation}

The change to the elliptical cross-section was made at set 138, approximately $25 \mathrm{~m}(80 \mathrm{ft}$ ) below the 7580 Level, or 2,630 m (8,628 ft) below ground surface. Pressure cells and extensometers were installed at set $140,2,640 \mathrm{~m}(8,668 \mathrm{ft})$ below surface, to better understand the magnitude and orientation of deformations, the time dependency of the displacements, and the load distribution in the liner.

Three $10 \mathrm{~m}$ ( $33 \mathrm{ft}$ ) multipoint borehole extensometers (Smart MPBX's), produced by Mine Design Technologies of Kingston, Ontario, were installed in $50 \mathrm{~mm}(2 \mathrm{in})$ boreholes, one each in the north, west, and south shaft walls. Four concrete pressure cells for monitoring of radially-oriented liner stress, model $4850-2$, and two 
stress cells oriented to monitor tangentially-oriented liner stress, model 4850-1, by Geokon of Lebanon, New Hampshire, were installed at the same elevation. The tangential cells were installed in the north and south shaft wall positions where they were expected to see the highest stresses (Figures 14 and 15).

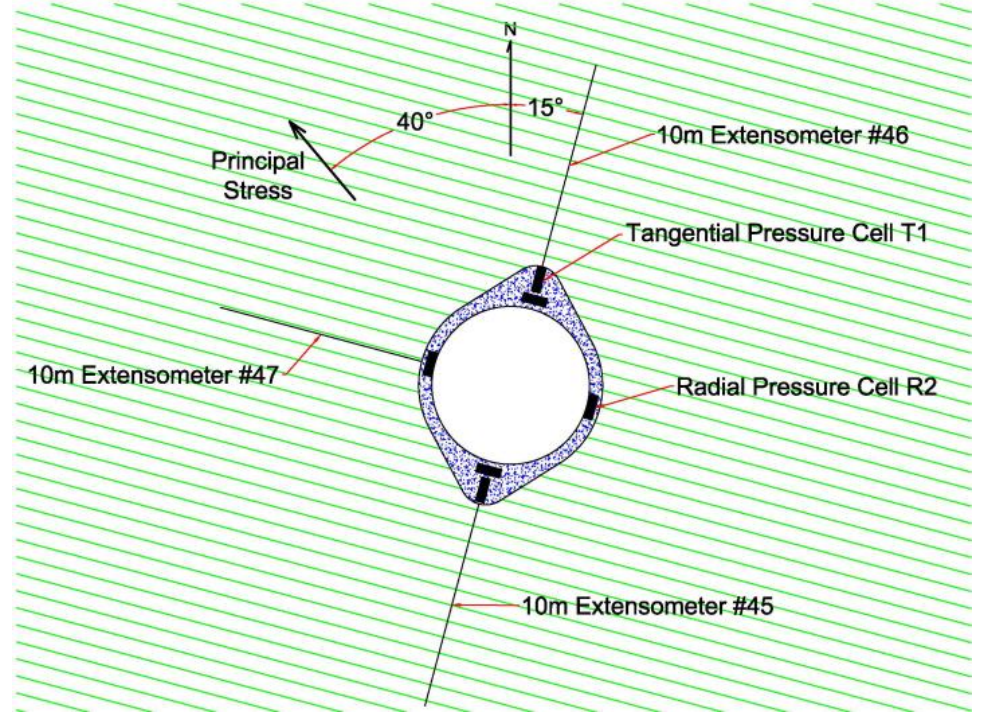

Figure 14 Plan view of instrumentation installation at set 140

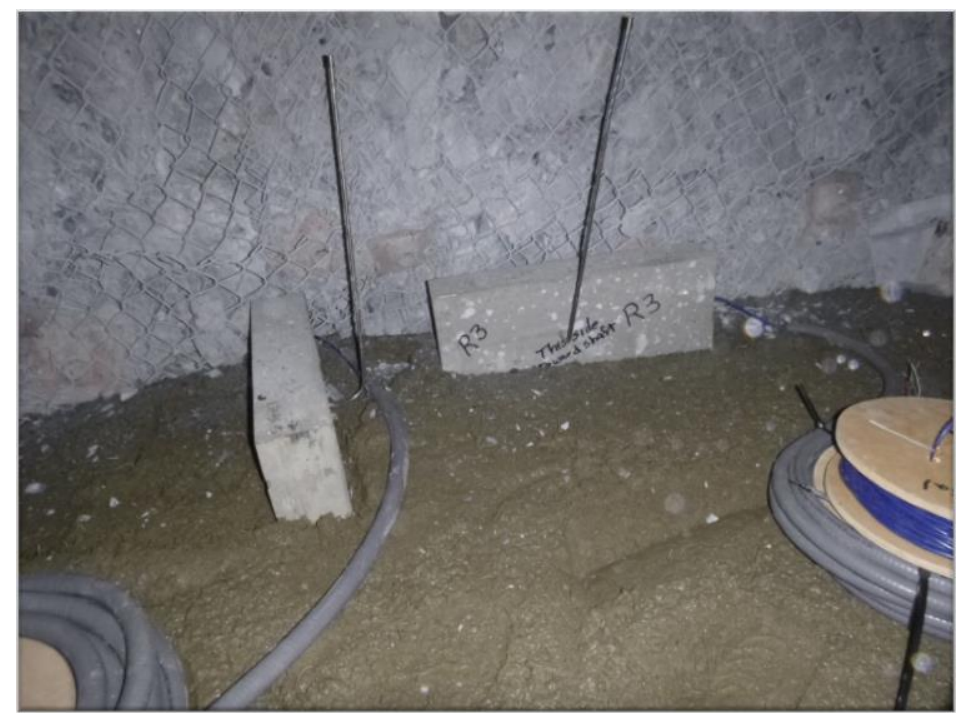

Figure 15 Instrumentation installation in south wall position of set 140

The pressure cells and extensometers were installed during the shaft liner concrete pour on 4 June 2015,

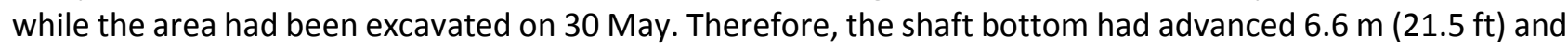
the shaft walls had five days to equilibrate prior to installation of the instruments and pouring of the concrete liner. Prior to being destroyed on 27 June, extensometer \#46 in the north wall of the shaft showed movement

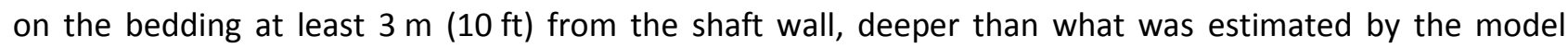
(Figure 16). The anchor at the collar showed a maximum displacement of $14 \mathrm{~mm}(0.55 \mathrm{in})$, while the anchor one metre in from the collar showed a displacement of $22.6 \mathrm{~mm}$ (0.9 inch). This differential can most likely be attributed to the dilation of the bedding near the shaft wall immediately after excavation. As soon as the concrete was placed and began to strengthen, the movement of the collar was arrested, while the surrounding rock mass deformed toward the shaft, compressing any dilated bedding near the liner contact. This north wall extensometer showed the greatest displacement of the three installed. Extensometer \#47 in the west wall of the excavation showed maximum displacement of only $1.3 \mathrm{~mm}(1 / 16 \mathrm{in})$, while extensometer \#45 in the south wall showed $18.3 \mathrm{~mm}$ (3/4 in). 
Smart MPBX: LF \#46_10 Meter

Set 140 - North Wall of Shaft

All Anchors Displayed

Installed just prior to concrete pour

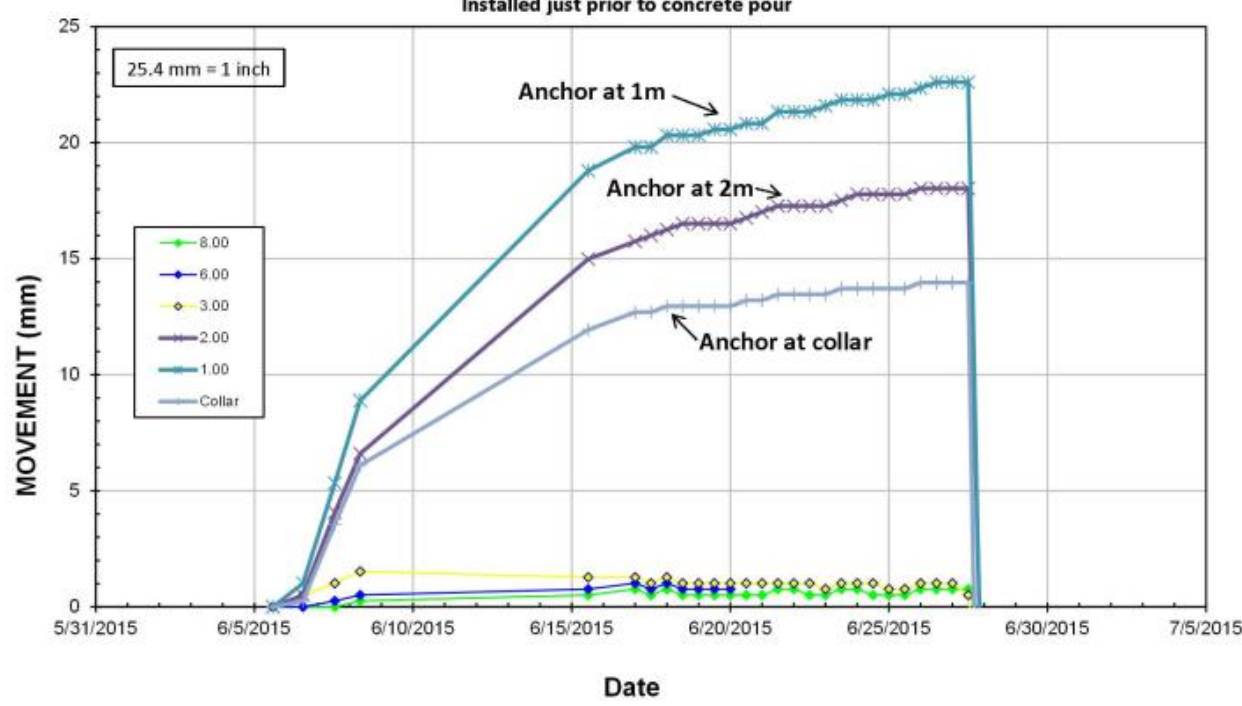

Figure 16 Extensometer \#46, installed in the north wall of the shaft

The maximum pressure (compression) in the liner was $10.9 \mathrm{MPa}(1,580 \mathrm{psi})$ recorded on 11 October 2015, at the north end of the elliptical excavation, in tangential pressure cell T1 (Figure 17). The rate of increase diminished as the concrete liner cured and shaft excavation moved away from the area. The highest compressive pressure seen by a cell oriented to monitor radial liner stress was in the east wall where, other than a few spikes caused by instrument sensitivity to temperature fluctuations, the pressure reached $6.5 \mathrm{MPa}$ (940 psi), (Figure 18). No liner cracking was observed after implementing the elliptical shape from set 138 to the eventual shaft bottom at 8620 Level. Temperature effects on pressure readings in stress cells in Figures 17 and 18 have been removed from values shown.

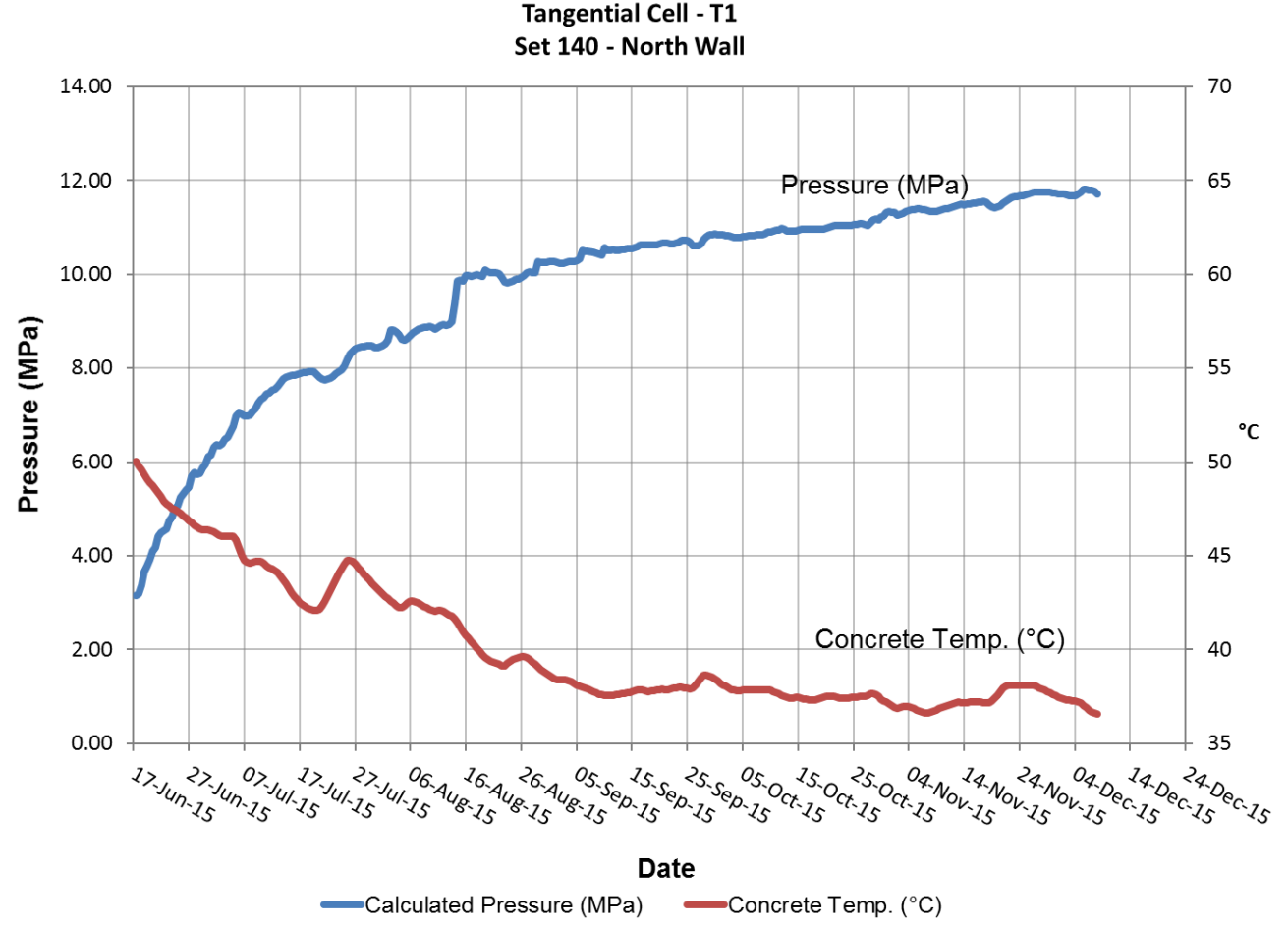

Figure 17 Tangential stress cell T1 (blue), north shaft wall, and concrete curing temperature (red) 


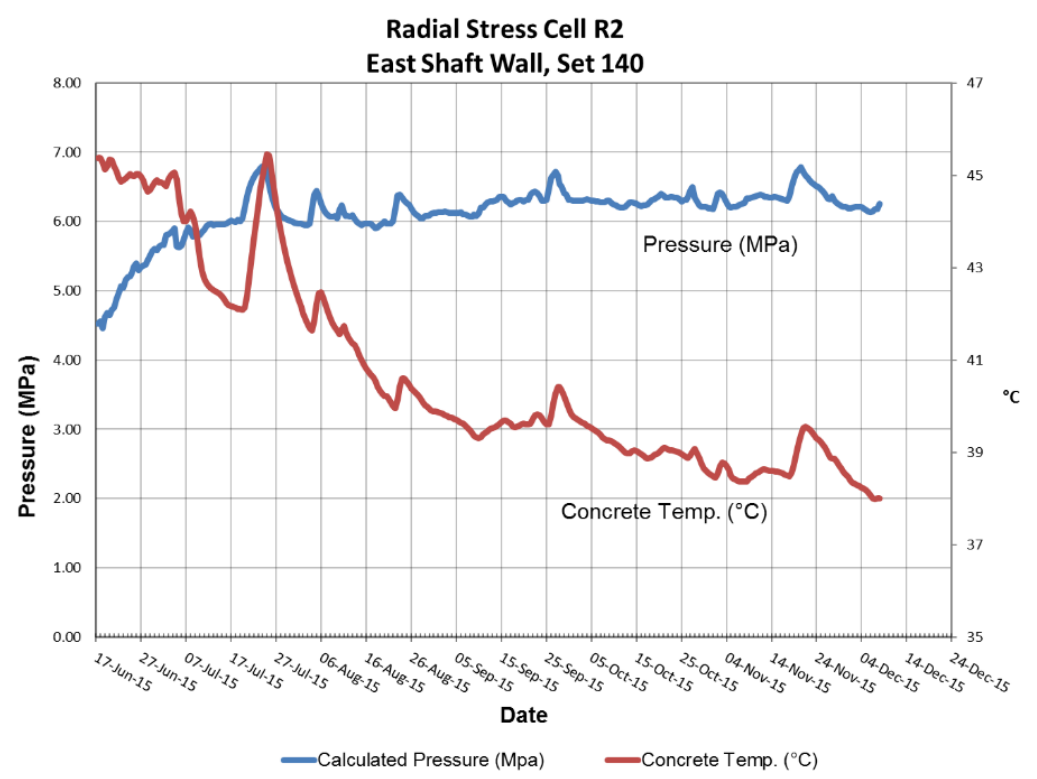

Figure 18 Radial stress cell R2 (blue), east shaft wall, and concrete curing temperature (red)

\section{$7 \quad$ Furnishing}

The shaft will be furnished with steel buntons and guides on $6.1 \mathrm{~m}(20 \mathrm{ft})$ spacing as shown in Figure 19. When the deformation was first observed, planning was initiated how best to furnish the shaft given the permanent deformation of the shaft liner. While it was known that deformation existed, the extent of the deformation was not well defined. Prior to the completion of sinking, an opportunity to better define the deformation was proposed by Cementation USA Inc. This plan involved high definition surveying of the shaft by using a 3D laser scanner to measure the variances in the shaft liner to a level never utilised in conjunction with furnishing before. Because the shaft was not sunk to full depth at this time, the scan was to be completed in two phases. The first phase would provide baseline data while there remained time to modify the permanent shaft steel if required. The second phase would take place after the completion of sinking and would scan the remainder of the shaft and re-scan key areas of the shaft as determined by phase one, including areas where additional deformation may have occurred.

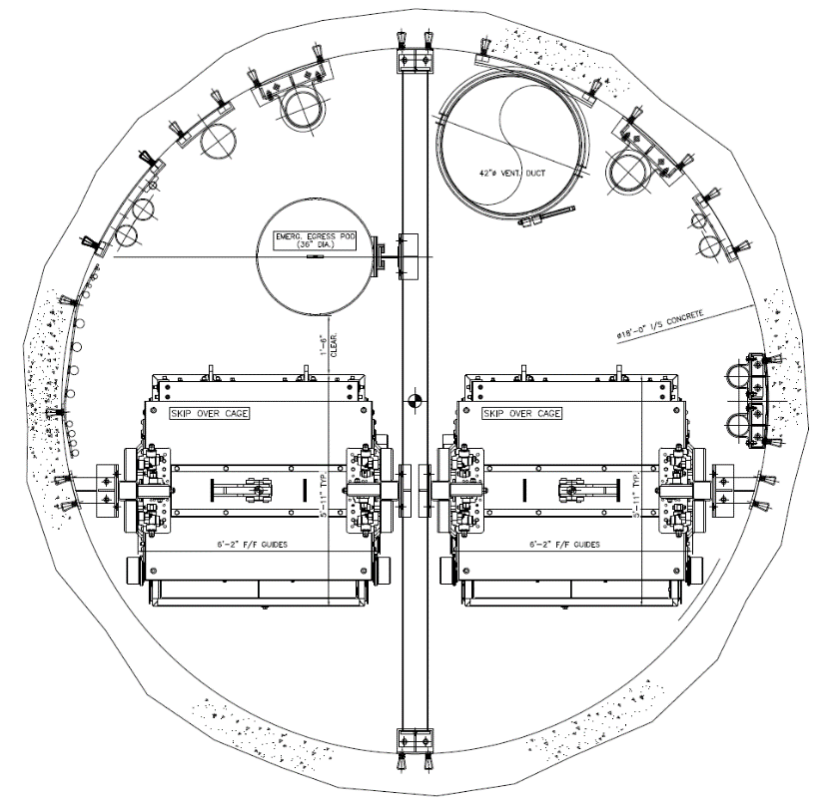

Figure 19 Typical shaft furnishing plan view 
The chosen equipment for the first phase was the Leica ScanStation P20, a portable unit capable of scanning one million survey points per second. This unit generated a model of the shaft with a minimum point density of 108,000 points per $\mathrm{m}^{2}$, sufficient accuracy and resolution for this analysis and to record defects on the face of the shaft liner. The methodology for scanning the shaft involved placing the scanner unit on an aluminium arm that was mounted to the shaft wall using two bolts into existing shaft steel inserts. A separate scan was

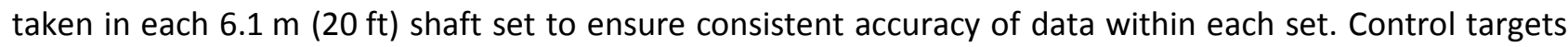
were placed in each scan and left in place for the adjacent scans, allowing all of the individual scans to be tied together with a high level of precision. The product of each scan was a point cloud, all of which were integrated and registered into AutoCAD files in which dimensional analysis could be completed. Dimensions were verified between the north and south steel inserts as well as the east and west inserts to model how the steel would fit at each set (see Figures 20 and 21).

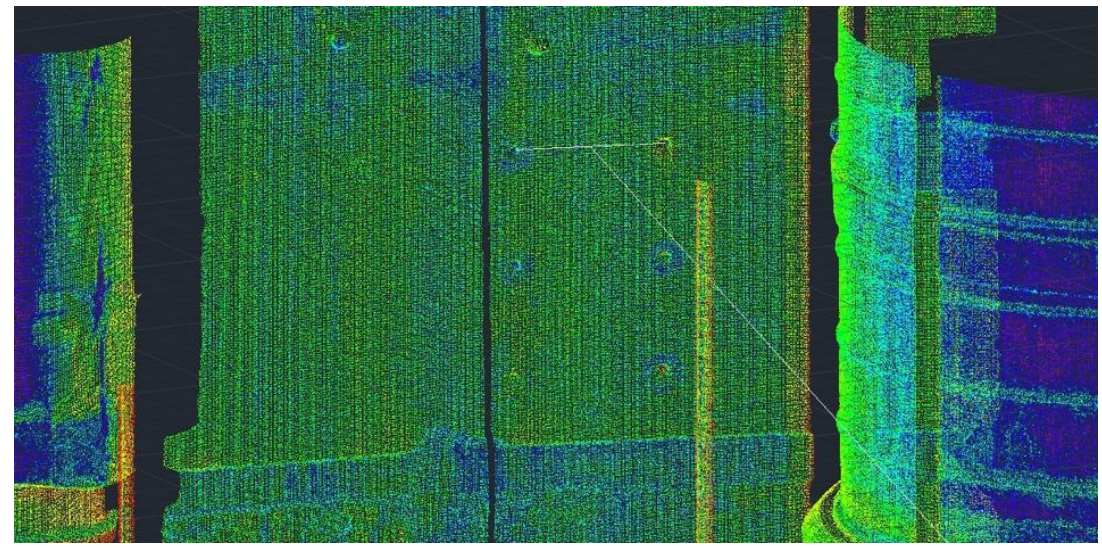

Figure 20 Dimensions were typically pulled from the midpoint of the top two inserts

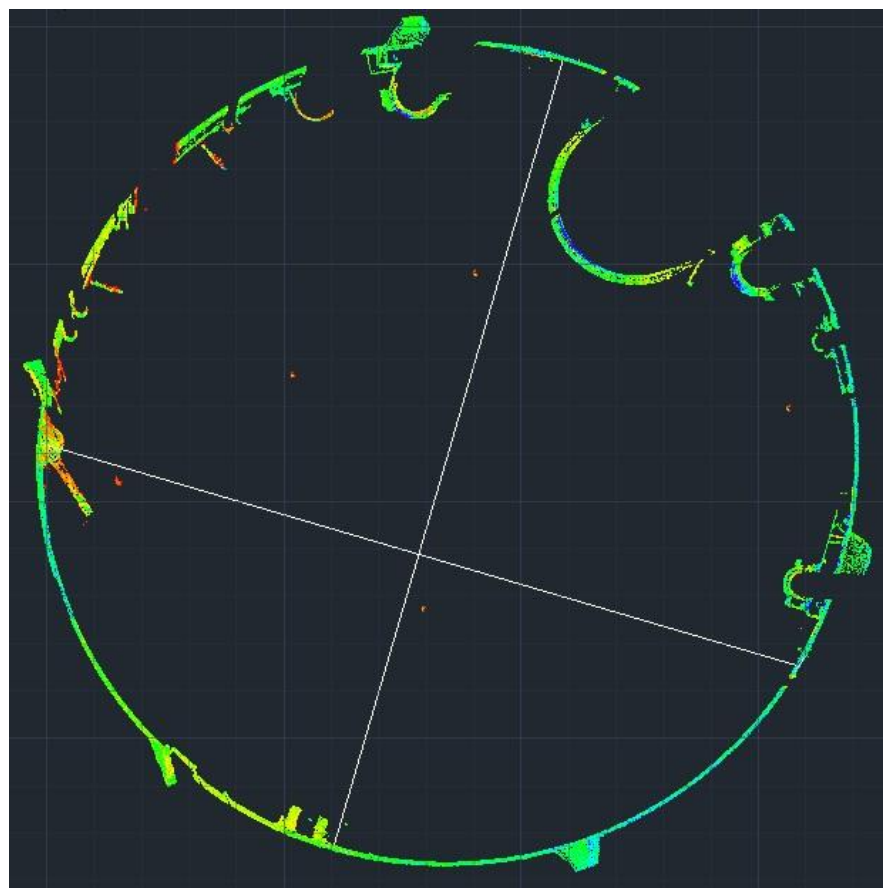

Figure 21 Typical shaft set scan data with dimension pulled between inserts

The dimensions from the scan model data were exported to an Excel file and collectively analysed relative to a common shaft centreline. This produced a deviation from design value for each of the four insert locations in each set. Analysing this data as a whole made clear the extent of the shaft liner deformation, and the decision was made to order modified wall brackets for the permanent shaft steel. It was decided to modify 
the wall bracket design because this would allow the guides to maintain their design location within the shaft barrel while the longer or shorter wall brackets accounted for any liner deformation in each set.

Three additional wall bracket styles were designed and procured to supplement the brackets of standard design: a long 'wide style' bracket, a short 'tight style $A$ ' bracket, and a shorter 'tight style B' bracket. Collectively, these four styles of brackets would cover liner deviation up to $44 \mathrm{~mm}$ (1-3/4 inches) wide of design and up to $79 \mathrm{~mm}$ (3-1/8 inches) tight of design, which was expected to cover the deviation in all but one location in the shaft.

At the completion of shaft sinking, phase two of the scan was performed using the newly released Leica ScanStation P40, an updated scanner model that provided a point density in excess of 430,000 points per $\mathrm{m}^{2}$

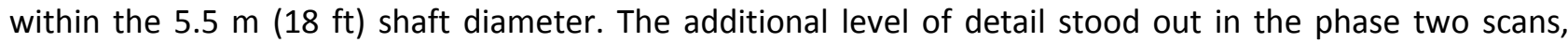
providing highly accurate models of the tightest, most crucial sections of the shaft. This new data did confirm that the tightest section of the shaft was still moving, further encroaching on what had already known to be tight conveyance clearances. Using shaft plumb line data pulled from the scan, the shaft steel was modelled through this portion of the shaft and it was determined that the conveyance clearances were less than required in this area. Two solutions were tested in the scan model: notching of the liner plate and grout in the two tightest locations, and a shifting of the compartments towards the centre of the shaft. The dimensions of the notches were estimated using the scan data to allow for methodology and equipment planning, and were then verified in the field prior to cutting. The compartment shift was accomplished by transitioning to narrower steel buntons through this area, allowing the conveyance compartments to shift closer to each other by $100 \mathrm{~mm}$ ( 4 in), increasing clearance from the shaft wall by $50 \mathrm{~mm}$ ( $2 \mathrm{in}$ ) on each side. The transitions into and out of the narrow bunton zone were designed to be smooth and gradual, with the goal of limiting any additional wear on the conveyance rollers and slippers as well as not overstressing any of the shaft steel due to the lateral loading.

The shaft plumb line data gathered from the scan, in conjunction with the liner variance data, was also used to model how the conveyances would travel through the rest of the shaft. This was critical to ensure that they maintained proper clearance from the shaft liner at all times, and that they would correctly align with the loading pockets, dump, and other production levels. It became apparent that the shaft steel could not be installed plumb through the full shaft due to horizontal variances. After the completion of sinking the plumb lines were reset at each set of steady brackets. All were adjusted using the same methodology that maintained the design distance of the south plumb line from the liner to maximise conveyance clearances. While untraditional and intentionally bringing the guide strings out of plumb, this method allowed the guides to follow the shaft deformation in a gradual manner.

As an additional training and testing supplement, a shaft furnishing training centre was established on surface, as shown in Figure 22.

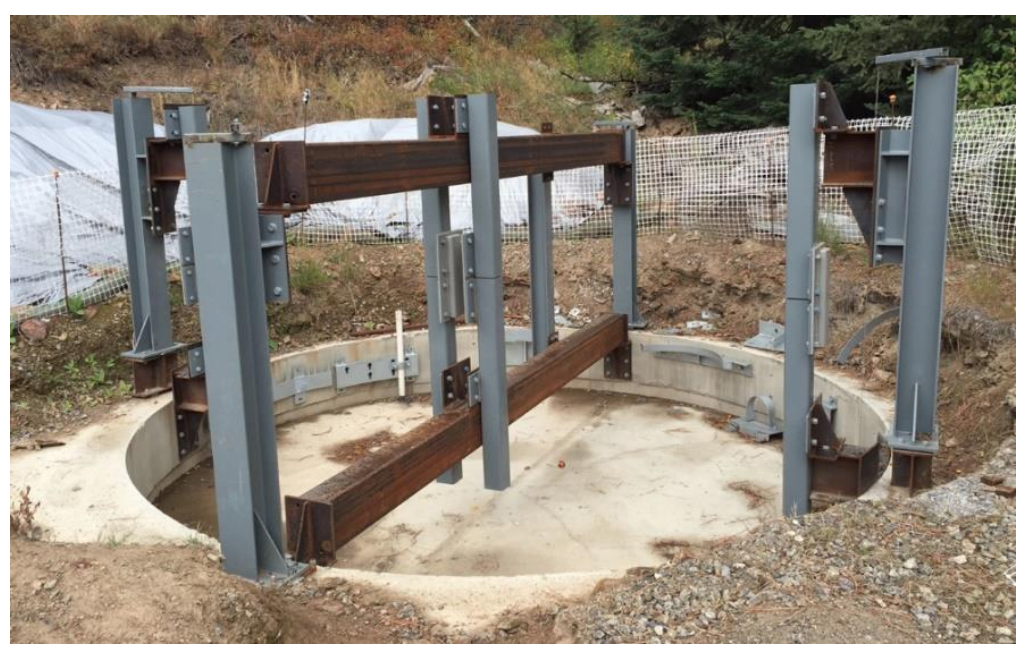

Figure 22 Surface training facility 
This mock-up of a typical shaft steel set was constructed by pouring an exact replica of the shaft liner A-ring in a small excavation, complete with bolt inserts for the shaft steel. Wall brackets were installed in the ring and the steel was constructed within it as a training exercise. All steel was full-scale, with the exception of the guides, which were shorter than a typical set for logistical reasons. The original intention of the centre was to train crews on the proper and safe installation of steel, a purpose that was fulfilled. However, the training centre also came to serve as a test centre for modifications and improvements, such as determining the best design for steel installation jigs, concrete and liner plate notching, and installation of modified wall brackets.

\section{$8 \quad$ Concluding remarks}

Over $284 \mathrm{~m}$ (930 ft) of shaft have been mined using the elliptical cross-section, with no evidence of cracking or other damage to the concrete liner. Pressures and deformations seen in the instrumentation at set 140, $2,640 \mathrm{~m}(8,668 \mathrm{ft})$ below surface, have not exceeded the liner strength. The 8300 production level, more than $2,830 \mathrm{~m}(9,290 \mathrm{ft})$ below the ground surface, is complete with no damage to the shaft liner. Further instrumentation has been installed to confirm the performance of the elliptical excavation between the 8300 and 8380 shaft stations, where the liner will be subjected to conditions similar to those that caused deformation and fracturing of the liner between the 7500 and 7580 Levels. Extensometers have been installed in the north and south shaft walls between the 6580 and 7500 Levels for long-term monitoring of the liner in the area of circular excavation.

The elliptical cross-section requires an additional $15 \%$ in excavation, $11 \%$ additional ground support, plus an equivalent $15 \%$ of concrete. A Review showed that the potential elimination of concrete repair work and steel liner plate installation would more than compensate for the additional excavation, support, and concrete. The change allowed the completion of the shaft to the designed shaft bottom at the 8620 Level, $2,923 \mathrm{~m}(9,589 \mathrm{ft})$ below the surface.

The data available from the construction sequence and instrumentation is continuing to be evaluated. Once complete, the evaluation may provide additional data on the following:

- The potential for modelling during the design work when the change in excavation shape was to have taken place.

- Maintenance and operating procedures for the \#4-Shaft facility.

- Long-term performance of the installed ground support.

\section{References}

Board, M, 2011, Geotechnical Trip Report to \#4 Shaft Project, Lucky Friday/Gold Hunter Mine, Technical Memorandum 1917, Itasca Denver, Inc., Lakewood, Colorado.

McWilliams, JR \& Erickson, EG 1960, Methods and Costs of Shaft Sinking in the Coeur d'Alene District, Shoshone County, ID, U.S. Bureau of Mines IC-7961.

Pakalnis, R 2008, Pre-Development Report (Geotechnical) to \#4 Shaft - Hecla Limited - Lucky Friday, Report No. LFM-2/08, Pakalnis and Associates.

Strickland, B, Board, M, Sturgis, G \& Berberick, D 2016, Elliptical Shaft Excavation in Response to Depth Induced Ground Pressure, SME Annual Meeting, paper 16-084. 
